\title{
Measures to Improve the Energy Efficiency of Street Lighting Systems in the Kharkiv City
}

\author{
Olena Didenko (D), Krystyna Suvorova (D), Olena Liashenko (D), Maria Sukhonos (D), \\ and Maria Liubchenko
}

O. M. Beketov National University of Urban Economy in Kharkiv, Kharkiv, Ukraine

\author{
Article History \\ Received: \\ 26 April 2021 \\ Accepted: \\ 30 August 2021 \\ Published online: \\ 29 October 2021

\section{Keywords \\ Street Lighting; \\ Energy Efficiency; \\ Light Sources; \\ Ballast; \\ Control Systems}

\begin{abstract}
High-quality street lighting improves visual perception of the road and provides for a significant decrease in the number of road accidents. It has been established that the total number of accidents can be reduced by $30 \%$ for national roads and by $45 \%$ for especially hazard areas (e.g., at intersections). Doubling of the average luminance of the road surface significantly reduces the number of accidents in the dark and twilight. Sufficient street lighting contributes to: reducing electricity consumption; decreasing operating costs; improving the environmental situation; promoting business, tourism and investment activity; decreasing the number of criminal offenses. The analysis of recent research and publications helped choose the best European practices which can be used to improve the outdoor lighting in Ukraine. The street lighting network is continuously growing and being modernized. Different types of light sources are being used in the network to illuminate the city. Today, high-pressure lamps (HPS) are leading. They are increasingly replaced by LED light sources. Not a small share is accounted for by metal-halide lamps. The smallest number of light sources in the street lighting system, high-pressure mercury and compact fluorescent lamps (CFLs). To increase the efficiency of the street lighting system and reduce energy consumption for its operation, measures for its reconstruction and modernization are required. For this purpose, it is necessary to address the following problems: high level of obsolescence and physical wear and tear of system elements; inefficient use and high losses of electricity at the stages of transportation and consumption, due to the use of obsolete and worn-out equipment; suboptimal distribution of the utility capacity, which leads to ineffective use of the existing lighting system; low efficiency of the street lighting control system, due to the lack of electric meters and remote monitoring and control of the street lighting. Introduction of energy-saving types of light sources is one of the ways to modernize the existing street lighting system. It is necessary to replace old lighting fixtures, which have already exhausted their life span, by new energy-saving light sources (replace CFLs by LEDs), use automatic control systems. All this in turn will help reduce energy costs by $60 \%$. To improve energy efficiency of the street lighting system, it is also recommended to carryout the replacement of electromagnetic ballasts by electronic ones. The employment of electronic ballasts, e.g., in case of using HPS 250 lamps, allows to save approximately $255 \mathrm{kWh}$ /year. Considering that the price per $\mathrm{kW}$ of electric energy is UAH 2.68, one luminaire helps save the amount of UAH 683.4 per year.
\end{abstract}

\section{INTRODUCTION}

It is known that high-quality street lighting improves visual perception of the road and provides for a significant decrease in the number of road accidents. It has been established that the total number of accidents can be reduced by $30 \%$ for national roads and by $45 \%$ for especially hazard areas (e.g., at intersections) [1-9].

The same results were obtained during the studies of the relationship between street lighting and road accidents [10-12], carried out at the initiative of the International Commission on Illumination (CIE). Doubling of the average luminance of the road surface significantly reduces the number of accidents in the dark and twilight. This was clearly demonstrated by experiments commissioned by the German

Corresponding author: olena.parhomenko@kname.edu.ua (Olena Didenko)

(c) 2021 The Author(s). Published by O. M. Beketov National University of Urban Economy in Kharkiv Use permitted under Creative Commons Attribution 4.0 International (CC BY 4.0)

Cite as: Didenko, O., Suvorova, K., Liashenko, O., Sukhonos, M., \& Liubchenko, M. (2021). Measures to improve the energy efficiency of street lighting systems in the Kharkiv city. Lighting Engineering \& Power Engineering, 60(2), 39-46. https://doi.org/10.33042/2079-424X.2021.60.2.01 
Ministry of Transport and carried out on ten road sections in six major cities. The number of road accidents decreased by $28 \%$. The number of road accidents involving pedestrians, cyclists, and motorcyclists declined by $68 \%$, and that of other accidents by $45 \%$.

In addition, high-quality street lighting contributes to:

- reducing electricity consumption (which is extremely important in the context of the economic crisis);

- decreasing operating costs;

- improving the environmental situation (reducing heating of the atmosphere, harmful emissions (waste disposal), light pollution;

- promoting business, tourism and investment activity.

Well-designed street lighting can also help prevent crime. Practice shows that acts of violence and crimes against property mainly take place in dark places, where criminals feel comfortable since under such circumstances, they are difficult to see and remember, and potential victims are practically helpless [13, 14]. An increase in the level of horizontal illumination in pedestrian zones, which is also accompanied by an increase in vertical illumination, contributes to a better visual space perception.

Analysis of recent studies and publications has shown that the designing of street lighting systems in accordance with the German standard DIN EN 13201-3 is one of the best positive European practices [15]. The main goal of this standard is to improve the visibility of streets and roads for all people using them. The implementation of its recommendations ensures the correct visual perception of the road surface and its boundaries, points of confluence and intersection of roads, direction of movement and possible obstacles, location of road users and their movements. In the end, a regime of safe continuous urban traffic is achieved.

Ukrainian and foreign authors pay much attention to mesopic photometry and its relationship with street lighting. For example, in works [1-9, 1618], the issue of achieving safety of people in the streets in the dark with the help of artificial lighting is analyzed. To determine the required power of lamps for replacing existing luminaires, it is recommended to use a mesopic photometric system, which allows performing calculations using the $S / P$ ratio. This ratio is considered to be an important characteristic of light sources.

The investigations of energy efficiency and energy saving is presented in works of Carli R., Dotoli M., Pellegrino R., Beccali M., Bonomolo M., Ciulla G., Galatioto A., Lo Brano V., et al. [19-25].

The existing street lighting systems have already exhausted their life span and become inefficient, which results in insufficient street lighting and irrational consumption of electricity.

The aim of the paper is to present measures for improving energy efficiency of street lighting systems in Kharkiv.

\section{STREET LIGHTING CLASSIFICATION}

Lighting of roads and adjacent areas is divided into the following subtypes $[2,15,20,26-33]$ :

- for the main transport routes. In such large-scale systems, powerful lamps (200-400 W) and lamps with reflectors, which concentrate the flow of light on the road, are used. They are installed on posts (poles) at a sufficient height. There are special requirements for fixing lamps and anchoring foundations of lamp posts;

- for by-pass routes. In these systems, 70-250 W lamps are employed. Along with reflex lighting, diffused lighting can be used. For this purpose, transparent relief shades are installed, which scatter the rays over a large area;

- for sidewalks, park and pedestrian zones, bike paths, transport stops. In such systems, diffused light from lamps with a power of about 40$125 \mathrm{~W}$ is used. The shape of the shade can be spherical or cylindrical. For better light diffusion, the shades can be equipped with additional transparent relief rings;

- lighting of information signs, which can be external and internal (built into the object). For this purpose, special lamps and spotlights are used;

- architectural highlighting, which needs to be thoroughly designed by landscape and architectural designers. Also, special lighting facilities are used, often of a special shape with decorative fastening elements.

\section{CURRENT STATE OF STREET LIGHTING SYSTEMS IN KHARKIV}

The street lighting network is continuously growing and being modernized.

In 2017, the total length of street lighting networks was $2498 \mathrm{~km}$ (Fig. 1, Tabl. 1), of which 51.2\% were cable networks and $48.8 \%$ - overhead networks.

The number of luminaires in the property of Misksvitlo, the municipal enterprise providing operation and servicing of street lighting networks in Kharkiv, was 80.822 ths. The distribution of luminaires by light source is shown in Fig. 2. The number of operative lighting fixtures by type of light source was 79.994 ths, that of non-operative ones comprised about $1.1 \%$ of the total amount. 


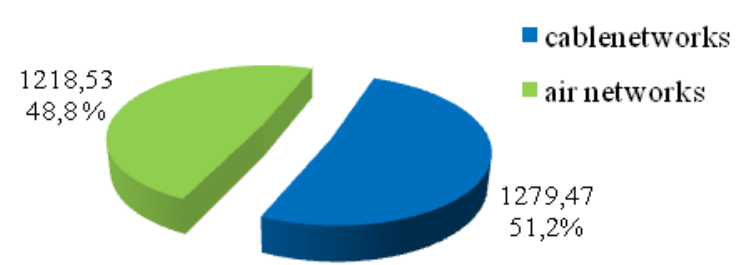

Figure 1. The length of street lighting networks in Kharkiv

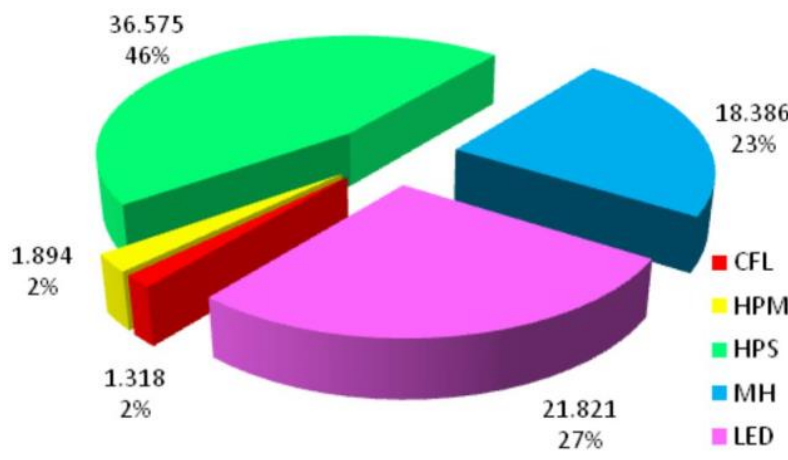

Figure 2. Distribution of luminaires by light source

The city installed 608 intelligent street lighting systems (remote control and GSM modules).

The number of meters used to measure electrical energy consumed by the city's street lighting sys- tems (including variable-rate electricity meters (Decree No. 2210 dated December 15 2016) totaled 0.752 ths.

The amount of electricity consumed for street lighting in the city was 31288.1 ths $\mathrm{kW} / \mathrm{h}$. The average amount of electricity consumed for the operation of one luminaire was $402 \mathrm{~kW} / \mathrm{h}$.

In 2018, Misksvitlo, at the expense of the city funds, allocated for the maintenance and current repair of street lighting facilities, installed $19.2 \mathrm{~km}$ of street lighting networks, replaced 14.6 ths electric lamps, repaired 3.9 ths lamps, etc.

Table 1. Balance of street lighting networks in Kharkiv

\begin{tabular}{lcccc}
\hline $\begin{array}{c}\text { Network } \\
\text { balance }\end{array}$ & 2016 & 2017 & 2018 & 2019 \\
\hline $\begin{array}{l}\text { The length of } \\
\text { street lighting } \\
\text { networks }\end{array}$ & 2442.75 & 2498 & 2517.2 & 2523.5 \\
\hline
\end{tabular}

As part of the implementation of the Comprehensive Program for Energy Saving in the city of Kharkiv for 2010-2020, 1.5 ths energy-efficient lamps were installed, the street lighting networks replaced with insulated ones, which made it possible to reduce electricity consumption.

Table 2. Street luminaires in Kharkiv

\begin{tabular}{|c|c|c|c|}
\hline No. & \multicolumn{2}{|c|}{ Characteristic } & Object, recreation area, alley \\
\hline 1 & \multicolumn{2}{|l|}{ Type of luminaire } & ZhTU* \\
\hline 2 & \multicolumn{2}{|l|}{ Type of light source (lamp) } & high-pressure sodium lamps (HPS) \\
\hline \multirow[t]{2}{*}{3} & \multicolumn{2}{|l|}{ Type of ballast } & electromagnetic ballast (lighting ballast) \\
\hline & & Lamps & 70 \\
\hline \multirow[t]{2}{*}{4} & \multirow[t]{2}{*}{ Power of one luminaire, $\mathrm{W}$} & Ballast & 70 \\
\hline & & Total & $120-130$ \\
\hline 5 & \multicolumn{2}{|c|}{ Number of luminaires per object, pcs. } & 40 \\
\hline 6 & \multicolumn{2}{|c|}{ Luminaire installation method } & crowning \\
\hline 7 & \multicolumn{2}{|l|}{ On the poles } & metal park luminaires \\
\hline 8 & \multicolumn{2}{|c|}{ Number of luminaires per pole } & 1 \\
\hline 9 & \multicolumn{2}{|c|}{ Number of poles } & 40 \\
\hline 10 & \multicolumn{2}{|c|}{ Type of arrangement of poles (luminaires) } & one-sided \\
\hline 11 & \multicolumn{2}{|c|}{ Distance between poles (luminaires), $\mathrm{m}$} & $\max 25$ \\
\hline 12 & \multicolumn{2}{|c|}{ Distance from poles to the edge of the road (curb) } & $0.5-1$ \\
\hline 13 & \multicolumn{2}{|c|}{ Angle of installation of luminaires in relation to the road, deg. } & 90 \\
\hline 14 & \multicolumn{2}{|c|}{ Height of installation of luminaires, $\mathrm{m}$} & 4 \\
\hline 15 & \multicolumn{2}{|c|}{ Width of the road, $\mathrm{m}$} & 1 \\
\hline 16 & \multicolumn{2}{|c|}{$\begin{array}{l}\text { Total installed power of luminaires (light sources with } \\
\text { the ballasts), } \mathrm{kW}\end{array}$} & 2.8 \\
\hline 17 & \multicolumn{2}{|c|}{ Percentage of operative luminaires } & $100 \%$ \\
\hline 18 & \multicolumn{2}{|c|}{ Actual average illuminance, $1 x$} & - \\
\hline 19 & \multicolumn{2}{|c|}{ Normative average illuminance, $1 \mathrm{x}$} & - \\
\hline 20 & \multicolumn{2}{|c|}{ Object of the municipal infrastructure } & Kitliarchyn Yar \\
\hline 21 & \multicolumn{2}{|c|}{ Total length, km } & 0.749 \\
\hline 22 & \multicolumn{2}{|c|}{ Total electricity consumed for street lighting, $\mathrm{kW} \mathrm{h}$} & 366 \\
\hline 23 & \multicolumn{2}{|c|}{ Cost of electricity for street lighting, UAH ths } & 938.15 \\
\hline
\end{tabular}

* Zh - sodium lamp type HPS; T - floor, crowning; U - for outdoor lighting 
The city street lighting networks were reconstructed: $143.6 \mathrm{~km}$ of networks, 5.3 ths luminaires and 4.4 ths poles were installed.

The work performed contributed to an increase in the level of lighting in the city by providing operation of $99.3 \%$ of luminaires. As of 2019, Misksvitlo completed the installation of $6.3 \mathrm{~km}$ of street lighting networks, 3.2 ths lamps being replaced. 371 energy-efficient lamps were installed, and the replacement of street lighting networks with insulated ones was carried out.

At the expense of the city funds, allocated for the reconstruction of street lighting networks, $27.9 \mathrm{~km}$ of networks, 826 luminaires and 409 poles, for the amount of UAH $12.4 \mathrm{mln}$, were installed in Kharkiv.

\section{STREET LIGHTING FACILITIES USED TODAY}

Let us consider street lighting using the example of a recreation area and alley, based on the data of Misksvitlo (Tabl. 2).

Kitliarchyn Yaris a pedestrian zone, recreational area with a spring and alleys. It can be attributed to the object class PZ traffic-free pedestrian precincts, main entrances to the territory of city-wide parks, sanatoriums; side entrances to and side alleys of exhibitions; side entrances to and central alleys of stadiums; access roads to gas stations from streets of category B. Table 3 shows the normative values for this object class.

Fig. 3 shows the light distribution in Kitliarchyn Yar. Having compared the normative and calculated values, we can see that the lighting of Kitliarchyn Yar is insufficient (Tabl. 4).

Table 3. Normative values for traffic-free pedestrian precincts

\begin{tabular}{cccc}
\hline Object class & $\begin{array}{c}\text { Average horizontal } \\
\text { illuminance, } E_{\text {aver, }}, \mathrm{lx}, \\
\text { no less than }\end{array}$ & $\begin{array}{c}E_{\text {min }} / E_{\text {aver }} \text { ratio, } \\
\text { no less than }\end{array}$ \\
\hline $\mathrm{P}$ & $\mathrm{PZ}$ & 4 & 0.35 \\
\hline
\end{tabular}

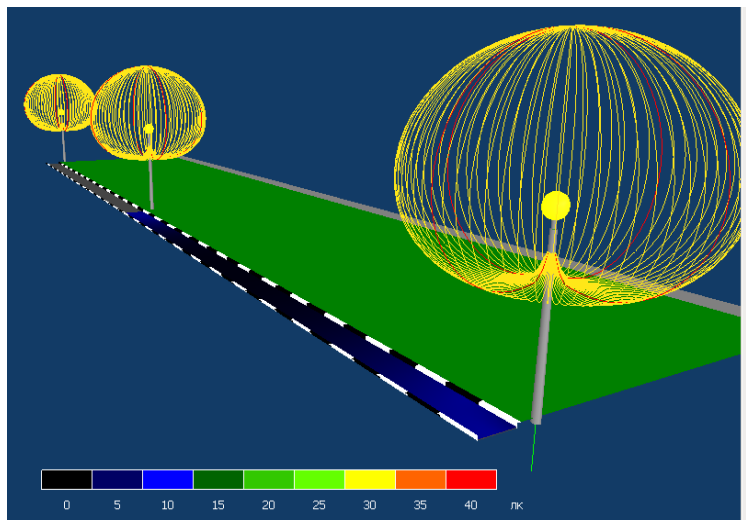

Figure 3. Light distribution in Kitliarchyn Yar (light source power - 70W)

Table 4. Normative and calculated values for Kitliarchyn Yar

\begin{tabular}{|c|c|c|c|c|c|}
\hline \multicolumn{2}{|c|}{ Object class } & \multirow{2}{*}{ Values obtained } & \multirow{2}{*}{$\begin{array}{l}\text { Light source pow- } \\
\text { er, W }\end{array}$} & \multirow{2}{*}{$\begin{array}{l}\text { Average horizontal illuminance, } \\
E_{\text {aver, }} 1 \mathrm{x} \text {, no less than }\end{array}$} & \multirow{2}{*}{$\begin{array}{c}E_{\min } / E_{\text {aver }} \text { ratio, } \\
\text { no less than }\end{array}$} \\
\hline Class & Subclass & & & & \\
\hline \multirow{4}{*}{$\mathrm{P}$} & \multirow{4}{*}{ PZ } & Normative values & - & 4 & 0.35 \\
\hline & & & 70 & 2.7 & 0.27 \\
\hline & & Calculated values & 150 & 5.8 & 0.32 \\
\hline & & & 150 & 10.3 & 0.35 \\
\hline
\end{tabular}

Table 5. Recommendations for improving the energy efficiency of the city pedestrian zone

\begin{tabular}{|c|c|c|c|c|c|}
\hline & & \multirow{2}{*}{ Employed } & \multicolumn{3}{|c|}{ Possible options } \\
\hline & & & Option 1 & Option 2 & Option 3 \\
\hline \multicolumn{2}{|c|}{ Type of luminaire } & ZhTU* & ZhTU* & ZhTU* & \\
\hline \multicolumn{2}{|c|}{ Type of light source (lamp) } & $\begin{array}{l}\text { high-pressure sodi- } \\
\text { um lamp (HPS) }\end{array}$ & $\begin{array}{l}\text { high-pressure so- } \\
\text { dium lamp (HPS) }\end{array}$ & $\begin{array}{l}\text { high-pressure sodium } \\
\text { lamp (HPS) }\end{array}$ & LED \\
\hline \multicolumn{2}{|l|}{ Type of ballast } & $\begin{array}{c}\text { electromagnetic } \\
\text { ballast (lighting } \\
\text { ballast) }\end{array}$ & $\begin{array}{l}\text { electromagnetic } \\
\text { ballast (lighting } \\
\text { ballast) }\end{array}$ & electronic ballast & $\begin{array}{l}\text { Employing } \\
\text { autonomous }\end{array}$ \\
\hline \multirow{3}{*}{$\begin{array}{l}\text { Power of one } \\
\text { luminaire, W }\end{array}$} & Lamps & 70 & 150 & 150 & lighting \\
\hline & Ballast & 70 & 150 & 150 & systems using \\
\hline & Total & $120-130$ & $195-205$ & $\begin{array}{l}150+\text { electronic } \\
\text { ballast efficiency }\end{array}$ & solar energy \\
\hline \multicolumn{2}{|c|}{$\begin{array}{l}\text { Type of arrangement of } \\
\text { poles (luminaires) }\end{array}$} & one-sided & one-sided & one-sided & \\
\hline
\end{tabular}

\footnotetext{
* Zh - sodium lamp type HPS; T - floor, crowning; U - for outdoor lighting
} 
Recommendations for improving lighting energy efficiency of Kitliarchyn Yar:

1 . It is necessary to replace the existing light sources with more powerful ones (Fig. 4) or even replace them by lighting fixtures with a different type of light curve (the so-called Pushkin's luminaires, resembling those used in the 19th century) (Fig. 5).

2. It is appropriate to replace electromagnetic ballasts by electronic ones (Tabl. 5).

3. To illuminate such places as Kitliarchyn Yar, it is expedient to employ autonomous lighting systems using solar energy.

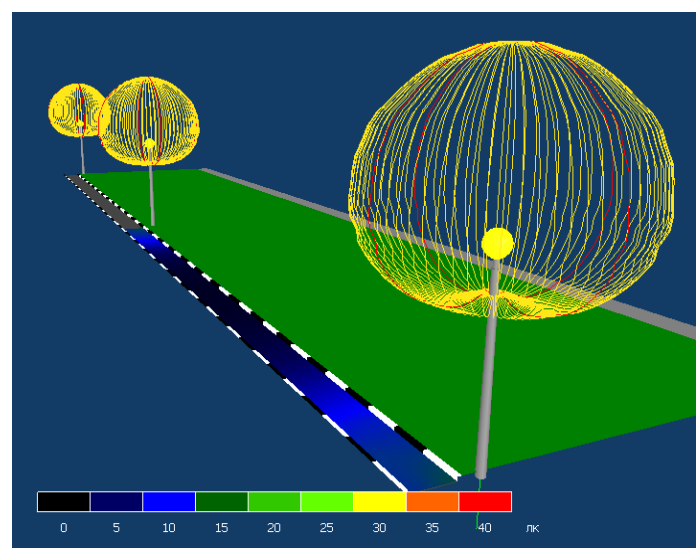

Figure 4. Light distribution in Kitliarchyn Yar (light source power - $150 \mathrm{~W}$ )

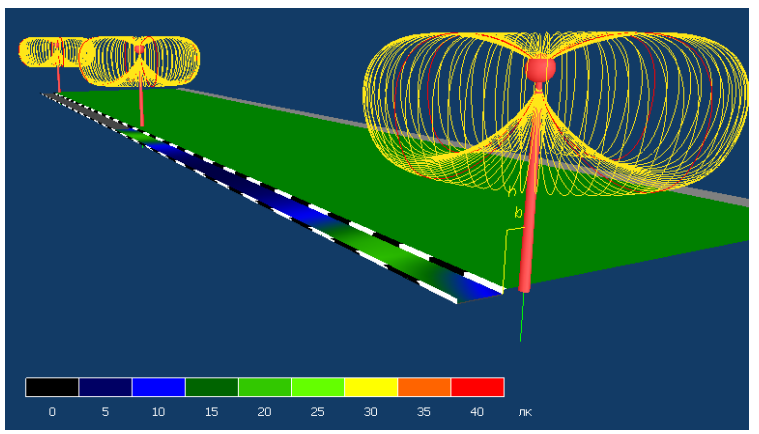

Figure 5. Light distribution in Kitliarchyn Yar (light source power - $150 \mathrm{~W}$ (Pushkin's luminaires))

To implement the program Energy Strategy of Ukraine for the period up to 2035 "Safety, Energy Efficiency, Competitiveness", in accordance with Directive 2012 / 27EU of the European Parliament and the Council of 25 October 2012 on energy efficiency, Kharkiv authorities need to ensure the introduction of energy-saving technologies in the lighting of city streets and municipal facilities.

To improve the efficiency of the street lighting system and reduce the energy consumption for its operation, measures for its reconstruction and modernization are required. For this purpose, it is essential to address the following problems:

- high level of obsolescence and physical wear and tear of system elements;
- inefficient use and high losses of electricity at the stages of transportation and consumption, due to the use of obsolete and worn-out equipment;

- suboptimal distribution of the utility capacity, which leads to ineffective use of the existing lighting system;

- low efficiency of the street lighting control system, due to the lack of electric meters and remote monitoring and control of the street lighting.

With regard to the mechanism for introducing energy efficient technologies, it is necessary to envisage the following measures:

1. Analyzing the lighting facility, identifying all factors and objects that affect the calculated data, and determining the category of the lighting facility.

2. For ensuring energy efficiency and reliability of the lighting system, when designing a new lighting facility or reconstructing an old one, it is necessary to choose equipment with high efficiency, appropriate design, which provides the necessary degree of protection against environmental factors, thermal regime, and spatial distribution of light.

3. For determining the most acceptable lighting option in terms of quantitative, qualitative and economic indicators, to carry out computer modeling of various lighting options using reliable databases of luminaires which have certificates of conformity issued by specialized measuring laboratories with equipment, the characteristics of which are checked against those of leading manufacturers of lighting products.

4. Checking the electrical and lighting characteristics of luminaires planned to be used for lighting systems, in case of the absence or doubtfulness of their quality certificate, with the receipt of a proper measurement report including the following specifications:

- luminous intensity, cd;

- luminous flux, lm;

- spectral quality of radiation, $\mathrm{nm}$;

- color temperature, $\mathrm{k}$;

- color rendering index;

- chromaticity coordinates;

- spatial light distribution (light intensity distribution curve), cd;

- operating voltage, $\mathrm{V}$;

- operating current, A;

- power consumption, W;

- power factor (PF);

- isolux and isocandela curves;

- maximum ratio of the distance between the luminaires and the height of the luminaire installation (for street lighting facilities (LF));

- utilization factor (UF);

- effective radiation angle; 
- radiation scattering angle;

- luminance limitation curves;

- values of current and voltage harmonic components;

- efficiency of the luminaire.

The results are presented in the form of test reports and photometric data files in the formats: IESNA (1995, 2002), Eulumdat, CIE, CEN, CIBSE, TM14.

All tests of luminaires should be carried out in certified laboratories.

5. Applying energy-saving types of light sources.

It is necessary to replace old lighting facilities, which have already exhausted their life span, with new ones with energy-saving light sources (replace CFLs by LEDs), to use automatic control systems, which will help reduce energy costs by $60 \%$.

6. Replacing electromagnetic ballasts with electronic ones.

The employment of electronic ballasts, e.g., in case of using HPS 250 lamps, allows to save approximately $255 \mathrm{kWh} /$ year. Considering that the price per $\mathrm{kW}$ of electric energy is UAH 2.68, one luminaire helps save the amount of UAH 683.4 per year.

7. To light areas where there is a lot of space, autonomous lighting systems using solar energy can be employed.

For achieving a greater economic effect of the use of autonomous lighting systems, it is necessary to design such a system for a particular lighting facility to meet lighting standards.

8. Autonomous lighting systems can be used to illuminate main streets, park areas with stations for recharging electric cars, electric scooters and other types of electric vehicles.

9. Implementing remote control and monitoring systems for street lighting.

In general, with the introduction of energysaving technologies in lighting, it is possible to save $79.33 \mathrm{mln}$. kWh of electricity, while burning by $10.42 \mathrm{mln} . \mathrm{m}^{3}$ of natural gas less than before.

\section{CONCLUSIONS}

Well-lit streets in the dark increase the productivity of the visual system and significantly reduce the number of accidents. To improve the efficiency of the street lighting system and reduce the energy consumption for its operation, measures for its reconstruction and modernization are required.

It is necessary to replace old lighting facilities, with new ones with energy-saving light sources, to use automatic control systems, which will help reduce energy costs by $60 \%$. Replacing electromagnetic ballasts with electronic ones.

\section{DISCLOSURE STATEMENT}

No potential conflict of interest was reported by the author(s).

\section{REFERENCES}

1. Marchant, P., Hale, J.D., \& Sadler, J.P. (2020). Does changing to brighter road lighting improve road safety? Multilevel longitudinal analysis of road traffic collision frequency during the relighting of a UK city. Journal of Epidemiology and Community Health, 74(5), 467-472. https://doi.org/10.1136/jech-2019-212208

2. CIE. (2019). Road Lighting Calculations, 2nd edition (CIE 140:2019). International Commission on Illumination. https://doi.org/10.25039/TR.140.2019

3. Li, M., Wu, P., Ding, J., Yao, Q., \& Ju, J. (2020). The circadian effect versus mesopic vision effect in road lighting applications. Applied Sciences, 10(19), 6975. https:/ / doi. org/10.3390/app10196975

4. Nazarenko, L., Kononenko, H., Mozharovska, T., \& Chernets, V. (2019). Mesopic photometry and street lighting. Metrology and Instruments, (2), 67-72. https://doi. org/10.33955/2307-2180(2)2019.67-72 (in Ukrainian)

5. Armas, J, \& Laugis, J. (2007). Road safety by improved road lighting: Road lighting measurements and analysis. In R.E. Lahtmets (Ed.) International Symposium "Topical problems of education in the field of electrical and power engineering" (pp. 83-90). Tallinn University of Technology. http://egdk.ttu.ee/files/kuressaare2007/kuressa are2007_83armas-laugis.pdf

6. Donatello, S., Quintero, R.R., Caldas, M.G., Wolf, O., Tichelen, P.V., Hoof, V.V., \& Geerken, T. (2019). Revision of the EU green public procurement criteria for road lighting and traffic signals (EUR 29631 EN). Publications Office of the European Union. https:// doi.org/10.2760/372897

7. Fotios, S., \& Gibbons, R. (2018). Road lighting research for drivers and pedestrians: The basis of luminance and illuminance recommendations. Lighting Research \& Technology, 50(1), 154-186. https://doi.org/10.1177/14771 53517739055

8. Jaskowski, P., \& Tomczuk, P. (2020). Analysis of the measurement plane change in street illumination measurements. In 2020 Fifth Junior Conference on Lighting (Lighting) (pp. 1-3). IEEE. https://doi.org/10.1109/ Lighting47792.2020.9240562

9. Bhagavathula, R., Gibbons, R.B., \& Nussbaum, M. A. (2018). Effects of intersection lighting design on nighttime visual performance of drivers. LEUKOS - Journal of Illuminating Engineering Society of North America, 14(1), 25 43. https:// doi.org/10.1080/15502724.2017.1321485

10. Green, J., Perkins, C., Steinbach, R., \& Edwards, P. (2015). Reduced street lighting at night and health: a rapid appraisal of public views in England and Wales. Health \& place, 34, 171-180. https://doi.org/10.1016/j.healthplace. 2015.05.011

11. Skandali, C., \& Lambiri, Y.S. (2018). Optimization of urban street lighting conditions focusing on energy saving, safety and users' needs. Journal of Contemporary Urban Affairs, 2(3), 112-121. https://doi.org/10.25034/ ijcua.2018.4726 
12. Ibrahim, A.H., Alharbi, F.A., Almoshaogeh, M.I., \& Elmadina, A.E.M. (2020). Literature review and a conceptual research framework of adaptive street lighting criteria. Engineering, Technology \& Applied Science Research, 10(4), 6004-6008. https:/ / doi.org/10.48084/etasr.3700

13. Xu, Y., Fu, C., Kennedy, E., Jiang, S., \& OwusuAgyemang, S. (2018). The impact of street lights on spatial-temporal patterns of crime in Detroit, Michigan. Cities, 79, 45-52. https:// doi.org/10.1016/j.cities.2018.02.021

14. Suk, J.Y., \& Walter, R.J. (2019). New nighttime roadway lighting documentation applied to public safety at night: A case study in San Antonio, Texas. Sustainable Cities and Society, 46, 101459. https://doi.org/10.1016/j. scs.2019.101459

15. Deutsches Institut für Normung. (2016). Road lighting - Part 3: Calculation of performance (DIN EN 13201-3).

16. Irwin, A. (2018). The dark side of light: how artificial lighting is harming the natural world. Nature, 553(7688), 268-271. https://doi.org/10.1038/d41586-01800665-7

17. Stone, T. (2018). The value of darkness: a moral framework for urban nighttime lighting. Science and Engineering Ethics, 24(2), 607-628. https://doi.org/10.1007/ s11948-017-9924-0

18. Meravi, N., \& Kumar Prajapati, S. (2020). Effect street light pollution on the photosynthetic efficiency of different plants. Biological Rhythm Research, 51(1), 67-75. https:/ / doi.org/10.1080/09291016.2018.1518206

19. Carli, R., Dotoli, M., \& Pellegrino, R. (2018). A decision-making tool for energy efficiency optimization of street lighting. Computers $\mathcal{E}$ Operations Research, 96, 223235. https://doi.org/10.1016/j.cor.2017.11.016

20. Didenko, O., Suvorova, K., Lyshenko, O., Sukhonos, M., \& Liubchenko, M. (2019). Current status and potential of energy efficiency of lighting systems of Kharkov city. Municipal Economy of Cities, 3(149), 2-8. https:// doi.org/10.33042/2522-1809-2019-3-149-2-8 (in Ukrainian)

21. Tatyanko, D.N., Neyezhmakov, P.I., Timofeev, Y.P., Litvinenko, A.S., Suvorova, K.I., \& Didenko, O.M. (2019). Quantum efficiency improvement of optical radiation trap-detectors. Semiconductor Physics, Quantum Electronics $\mathcal{E}$ Optoelectronics, 22(1), 104-110. https://doi.org/10. 15407/spqeo22.01.104

22. Pliuhin, V., \& Teterev, V. (2021). Possibility implementation analysis of the Smart Grid network in a current state conditions of the united energy systems of Ukraine. Lighting Engineering \& Power Engineering, 60(1), 15-22. https:/ / doi.org/10.33042/2079-424X.2021.60.1.03

23. Neyezhmakov, P.I., Lyashenko, O.M., Tymofeiev, E.P., Kupko, O.D., \& Litvinenko, A.S. (2019). Increasing the measurement accuracy of wide-aperture photometer based on digital camera. Journal of Nano- and Electronic
Physics, 11(3), 03029-1. https://doi.org/10.21272/jnep. 11(3).03029

24. Neyezhmakov, P., Liashenko, O., \& Timofeev, E. (2018). Increasing the reliability of calculation methods for determining illuminance. Ukrainian Metrological Journal, (2), 26-33. https:/ / doi.org/10.24027/2306-7039.2.2018.142032

25. Beccali, M., Bonomolo, M., Ciulla, G., Galatioto, A., \& Brano, V.L. (2015). Improvement of energy efficiency and quality of street lighting in South Italy as an action of Sustainable Energy Action Plans. The case study of Comiso (RG). Energy, 92, 394-408. https://doi.org/10.1016/ j.energy.2015.05.003

26. Sun, C.C., Lee, X.H., Moreno, I., Lee, C.H., Yu, Y.W., Yang, T.H., \& Chung, T.Y. (2017). Design of LED street lighting adapted for free-form roads. IEEE Photonics Journal, 9(1), 1-13. https://doi.org/10.1109/JPHOT.2017. 2657742

27. Varesi, K., Hosseini, S.H., Sabahi, M., Babaei, E., Saeidabadi, S., \& Vosoughi, N. (2018). Design and analysis of a developed multiport high step-up DC-DC converter with reduced device count and normalized peak inverse voltage on the switches/diodes. IEEE Transactions on Power Electronics, 34(6), 5464-5475. https://doi.org/ 10.1109/TPEL.2018.2866492

28. Omar, M.H., Rahman, H.A., Majid, M.S., Rosmin, N., Hassan, M.Y., \& Omar, W.W. (2013). Design and simulation of electronic ballast performance for high pressure sodium street lighting. Lighting Research $\mathcal{E}$ Technology, 45(6), 729739. https://doi.org/10.1177/1477153512471365

29. Casagrande, C., Nogueira, F., Salmento, M., \& Braga, H. (2019). Efficiency in street lighting projects by employing LED luminaires and mesopic photometry. IEEE Latin America Transactions, 17(06), 921-929. https://doi. org/10.1109/TLA.2019.8896814

30. Knobloch, F., \& Braunschweig, N. (2017). A trafficaware moving light system featuring optimal energy efficiency. IEEE Sensors Journal, 17(23), 7731-7740. https:/ /doi.org/10.1109/JSEN.2017.2669398

31. Cheng, B., Chen, Z., Yu, B., Li, Q., Wang, C., Li, B., ... \& Wu, J. (2020). Automated extraction of street lights from JL1-3B nighttime light data and assessment of their solar energy potential. IEEE Journal of Selected Topics in Applied Earth Observations and Remote Sensing, 13, 675-684. https://doi.org/10.1109/JSTARS.2020.2971266

32. Kyba, C.C.M., Ruby, A., Kuechly, H.U., Kinzey, B., Miller, N., Sanders, J., ... \& Espey, B. (2021). Direct measurement of the contribution of street lighting to satellite observations of nighttime light emissions from urban areas. Lighting Research $\mathcal{E}$ Technology, 53(3), 189-211. https://doi.org/10.1177/1477153520958463

33. State Building Norms of Ukraine. (2018). Nature and artificial lighting (DBN B.2.5-28-2018). (in Ukrainian).

\title{
Заходи щодо підвищення енергоефективності систем зовнішнього освітлення міста Харкова
}

\author{
Олена Діденко, Кристина Суворова, Олена Ляшенко, Марія Сухонос, Марія Любченко
}

Анотація. Якісне зовнішнє освітлення покращує візуальне сприйняття дороги та значно зменшує кількості дорожньо-транспортних пригод. Встановлено, що загальна кількість ДТП може бути зменшена на 30\% для доріг загального користування та на $45 \%$ для особливо небезпечних зон (наприклад перехрестях). Подвоєння серед- 
ньої яскравості дорожнього покриття значно зменшує кількість ДТП у темряві та сутінках. Достатнє вуличне освітлення сприяє: скороченню споживання електроенергії;зниженню експлуатаційних витрат; покращенню екологічної ситуації; сприянню бізнесу, туризму та інвестиційній діяльності; зменшенню кількості кримінальних правопорушень. Аналіз останніх досліджень та публікацій допоміг обрати найкращі європейські практики, які можна використати для покращення зовнішнього освітлення в Україні. Мережа вуличного освітлення постійно зростає та модернізується. Для освітлення міста в мережі використовуються різні види джерел світла. Сьогодні лідирують лампи високого тиску (ДНаТ), які все частіше замінюються світлодіодними джерелами світла. Не мала частка припадає на метало-галогенні лампи. Найменша кількість джерел світла в системі зовнішнього освітлення є ртуті високого тиску та компактних люмінесцентних ламп (КЛЛ). Для підвищення ефективності системи вуличного освітлення ії функціонування та зменшення споживання енергії необхідні заходи щодо ії реконструкції та модернізації. Для цього необхідно вирішити такі проблеми: високий рівень застарілості та фізичного зносу елементів системи; неефективне використання та великі втрати електроенергії на етапах транспортування та споживання, через використання застарілого та зношеного обладнання; неоптимальний розподіл потужності комунального підприємства, що призводить до неефективного використання існуючої системи освітлення; низька ефективність системи управління вуличним освітленням, через відсутність електролічильників та дистанційного контролю та управління вуличним освітленням. Впровадження енергозберігаючих видів джерел світла один із шляхів модернізації існуючої системи зовнішнього освітлення. Необхідно замінити старі освітлювальні прилади, які вже вичерпали свій термін служби, на нові енергозберігаючі джерела світла (замінити КЛЛ на світлодіоди), використовувати автоматичні системи управління. Все це в свою чергу допоможе знизити витрати на енергію на $60 \%$. Для підвищення енергоефективності системи зовнішнього освітлення також рекомендується проводити заміну електромагнітних баластів на електронні. Використання електронних баластів, наприклад, у разі використання ламп ДНаТ 250, дозволяє заощадити приблизно 255 кВт год/рік. Враховуючи, що ціна за кВт електричної енергії становить 2,68 грн., один світильник допомагає заощадити суму 683,4 грн. на рік.

Ключові слова: зовнішнє освітлення, енергозбереження, джерела світла, пускорегулююча апаратура, системи керування.

\section{NOTES ON CONTRIBUTORS}

\section{Olena Didenko}

olena.parhomenko@kname.edu.ua

\section{Krystyna Suvorova}

kisuvorova17@gmail.com

\author{
Olena Liashenko \\ happy.light9574@gmail.com
}

Maria Sukhonos
khg@kname.edu.ua

Maria Liubchenko

mariia.liubchenko@kname.edu.ua
Ph.D., Assistant Professor

Department of Lighting Engineering and Lighting Sources

O. M. Beketov National University of Urban Economy in Kharkiv, Kharkiv, Ukraine

(iD) https://orcid.org/0000-0001-8219-7692

p https://publons.com/researcher/J-9305-2016/

sC https://www.scopus.com/authid/ detail.uri?authorId=57209309085

Ph.D., Associate Professor

Department of Lighting Engineering and Lighting Sources

O. M. Beketov National University of Urban Economy in Kharkiv, Kharkiv, Ukraine (iD) https://orcid.org/0000-0001-8687-3547

https://www.scopus.com/authid/detail.uri?authorId=57209301429

Ph.D., Associate Professor

Department of Lighting Engineering and Lighting Sources

O. M. Beketov National University of Urban Economy in Kharkiv, Kharkiv, Ukraine

(iD) https://orcid.org/0000-0002-8835-8677

p https://publons.com/researcher/D-2239-2018/

SC https://www.scopus.com/authid/detail.uri?authorId=57209644105

D.Sc., Professor

Vice-Rector on Scientific Work

O. M. Beketov National University of Urban Economy in Kharkiv, Kharkiv, Ukraine

https://orcid.org/0000-0002-7246-8740

https:/ / www.scopus.com/authid/ detail.uri?authorId=57192202030

Ph.D., Associate Professor

Department of Fundamentals of Architectural Design

O. M. Beketov National University of Urban Economy in Kharkiv, Kharkiv, Ukraine

iD https://orcid.org/0000-0002-0425-7087

p https://publons.com/researcher/U-2125-2018/ 